\title{
Factors influencing the composition of the intestinal microbiota in early infancy
}

Citation for published version (APA):

Penders, J., Thijs, C., Vink, C., Stelma, F. F., Snijders, B. E. P., Kummeling, I., van den Brandt, P. A., \& Stobberingh, E. E. (2006). Factors influencing the composition of the intestinal microbiota in early infancy. Pediatrics, 118(2), 511-521. https://doi.org/10.1542/peds.2005-2824

Document status and date:

Published: 01/01/2006

DOI:

10.1542/peds.2005-2824

Document Version:

Publisher's PDF, also known as Version of record

\section{Please check the document version of this publication:}

- A submitted manuscript is the version of the article upon submission and before peer-review. There can be important differences between the submitted version and the official published version of record.

People interested in the research are advised to contact the author for the final version of the publication, or visit the DOI to the publisher's website.

- The final author version and the galley proof are versions of the publication after peer review.

- The final published version features the final layout of the paper including the volume, issue and page numbers.

Link to publication

\footnotetext{
General rights rights.

- You may freely distribute the URL identifying the publication in the public portal. please follow below link for the End User Agreement:

www.umlib.nl/taverne-license

Take down policy

If you believe that this document breaches copyright please contact us at:

repository@maastrichtuniversity.nl

providing details and we will investigate your claim.
}

Copyright and moral rights for the publications made accessible in the public portal are retained by the authors and/or other copyright owners and it is a condition of accessing publications that users recognise and abide by the legal requirements associated with these

- Users may download and print one copy of any publication from the public portal for the purpose of private study or research.

- You may not further distribute the material or use it for any profit-making activity or commercial gain

If the publication is distributed under the terms of Article $25 \mathrm{fa}$ of the Dutch Copyright Act, indicated by the "Taverne" license above, 


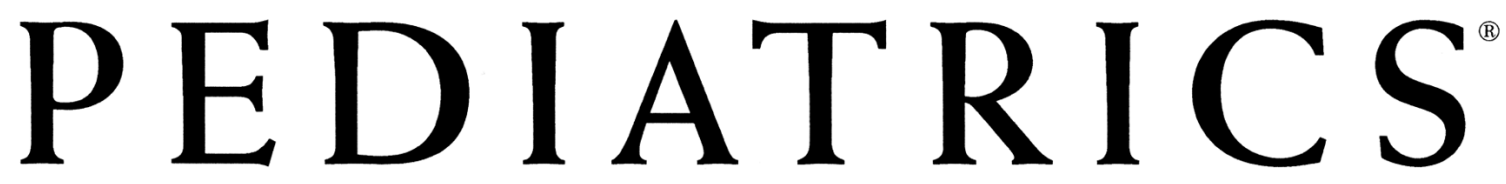

OFFICIAL JOURNAL OF THE AMERICAN ACADEMY OF PEDIATRICS

\section{Factors Influencing the Composition of the Intestinal Microbiota in Early Infancy}

John Penders, Carel Thijs, Cornelis Vink, Foekje F. Stelma, Bianca Snijders, Ischa Kummeling, Piet A. van den Brandt and Ellen E. Stobberingh

Pediatrics 2006;118;511-521

DOI: $10.1542 /$ peds.2005-2824

The online version of this article, along with updated information and services, is located on the World Wide Web at:

http://www.pediatrics.org/cgi/content/full/118/2/511

PEDIATRICS is the official journal of the American Academy of Pediatrics. A monthly publication, it has been published continuously since 1948. PEDIATRICS is owned, published, and trademarked by the American Academy of Pediatrics, 141 Northwest Point Boulevard, Elk Grove Village, Illinois, 60007. Copyright ( 2006 by the American Academy of Pediatrics. All rights reserved. Print ISSN: 0031-4005. Online ISSN: 1098-4275.

\section{American Academy of Pediatrics}

DEDICATED TO THE HEALTH OF ALL CHILDREN ${ }^{m}$ 


\title{
Factors Influencing the Composition of the Intestinal Microbiota in Early Infancy
}

\author{
John Penders, MSca, Carel Thijs, MD, PhD a,b, Cornelis Vink, PhDc, Foekje F. Stelma, MD, PhDc, Bianca Snijders, MSc ${ }^{b}$, Ischa Kummeling, MSc ${ }^{b}$, \\ Piet A. van den Brandt, PhDa ${ }^{a}$ Ellen E. Stobberingh, $\mathrm{PhD}^{c}$
}

aDepartment of Epidemiology, Nutrition and Toxicology Research Institute Maastricht, Maastricht University, Maastricht, Netherlands; bDepartment of Epidemiology, Care and Public Health Research Institute, Maastricht University, Maastricht, Netherlands; 'Department of Medical Microbiology, University Hospital of Maastricht, Maastricht, Netherlands

The authors have indicated they have no financial relationships relevant to this article to disclose.

\section{ABSTRACT}

OBJECTIVE. The aim of this study was to examine the contribution of a broad range of external influences to the gut microbiotic composition in early infancy.

METHODS. Fecal samples from 1032 infants at 1 month of age, who were recruited from the KOALA Birth Cohort Study in the Netherlands, were subjected to quantitative real-time polymerase chain reaction assays for the enumeration of bifidobacteria, Escherichia coli, Clostridium difficile, Bacteroides fragilis group, lactobacilli, and total bacterial counts. Information on potential determinants of the gut microbiotic composition was collected with repeated questionnaires. The associations between these factors and the selected gut bacteria were analyzed with univariate and multivariate analyses.

RESULTS. Infants born through cesarean section had lower numbers of bifidobacteria and Bacteroides, whereas they were more often colonized with $C$ difficile, compared with vaginally born infants. Exclusively formula-fed infants were more often colonized with E coli, $C$ difficile, Bacteroides, and lactobacilli, compared with breastfed infants. Hospitalization and prematurity were associated with higher prevalence and counts of $C$ difficile. Antibiotic use by the infant was associated with decreased numbers of bifidobacteria and Bacteroides. Infants with older siblings had slightly higher numbers of bifidobacteria, compared with infants without siblings.

CONCLUSIONS. The most important determinants of the gut microbiotic composition in infants were the mode of delivery, type of infant feeding, gestational age, infant hospitalization, and antibiotic use by the infant. Term infants who were born vaginally at home and were breastfed exclusively seemed to have the most "beneficial" gut microbiota (highest numbers of bifidobacteria and lowest numbers of $C$ difficile and $E$ coli). www.pediatrics.org/cgi/doi/10.1542/ peds.2005-2824

doi:10.1542/peds.2005-2824

Key Words

infant, intestinal microbiota, bacterial colonization, 16S ribosomal RNA, real-time polymerase chain reaction

Abbreviations

$P C R$ - polymerase chain reaction

CFU—colony-forming units

OR - odds ratio

$\mathrm{Cl}$ - confidence interval

Accepted for publication Feb 23, 2006

Address correspondence to John Penders, MSc, Department of Epidemiology, Nutrition and Toxicology Research Institute Maastricht, Maastricht University, PO Box 616, 6200 MD Maastricht, Netherlands. E-mail: j.penders@ epid.unimaas.nl

PEDIATRICS (ISSN Numbers: Print, 0031-4005; Online, 1098-4275). Copyright $\odot 2006$ by the American Academy of Pediatrics 
$\mathrm{T}$ HE GUT MICROBIOTA plays an important role in human health by providing a barrier for colonization of pathogens, by exerting important metabolic functions (fermentation of nondigestible fibers, salvage of energy as short-chain fatty acids, and production of vitamin $\mathrm{K}$ ), and by stimulating the development of the immune system. ${ }^{1}$ Bifidobacteria and lactobacilli are considered the most important health-beneficial bacteria for the human host, whereas bacteria such as staphylococci and clostridia are potentially pathogenic. ${ }^{2}$ Because the gut microbiota is involved in many aspects of human health, it is important to understand how the composition of this microbial ecology is established.

During early life, there are major changes in the composition of the intestinal microbiota. At birth, the intestines are sterile. Within a few hours, bacteria start to appear in the feces. Because the intestinal environment of neonates shows a positive oxidation/reduction potential at birth, the gastrointestinal tract is colonized first by facultative aerobes. Gradually, the consumption of oxygen by these bacteria changes the intestinal environment into a more-reduced one, permitting the subsequent growth of strict anaerobes. ${ }^{3}$

The bacteria colonizing the infant gut during the first days of life originate mainly from the mother and the environment. In early life, one of the first major determinants of the gut microbiota is the mode of delivery. Vaginally born infants are colonized at first by fecal and vaginal bacteria of the mother, whereas infants born through cesarean section are exposed initially to bacteria originating from the hospital environment and health care workers. ${ }^{3,4}$ Other factors that can influence the composition of the intestinal microbiota in neonates are the environment during birth, prematurity, hygiene measures, and the type of infant feeding. ${ }^{5}$ We showed previously that breastfed infants had less Clostridium difficile and Escherichia coli in their feces at the age of 1 month, compared with formula-fed infants, whereas counts of bifidobacteria were comparable in the 2 groups. ${ }^{6}$

Although determinants of gut microbiotic composition were investigated previously in several studies, those studies focused on only 1 or a few determinants at a time and generally involved a limited number of infants. ${ }^{7-11}$ Many potential determinants of the intestinal microbiota are clustered. For example, infants born through cesarean section need to stay in the hospital more often and receive antibiotics more frequently than do infants born vaginally. Consequently, the effects of individual determinants on the composition of the intestinal microbiota can be distinguished only if a large population is studied.

The aim of this study was to examine the influence of a broad range of potential determinants of gut microbiotic composition in a prospective cohort study in the Netherlands. Fecal samples of $>1000$ infants, 1 month of age, were analyzed with real-time polymerase chain reaction (PCR) assays, to detect quantitatively several bacterial groups and species.

\section{METHODS}

\section{Subjects and Study Design}

The KOALA Birth Cohort Study is a prospective birth cohort in the Netherlands. The design of this study was described in detail elsewhere. ${ }^{12}$ Briefly, from October 2000 until December 2002, we recruited participants with diverse lifestyles, at 34 weeks of gestation. Pregnant women with a conventional lifestyle $(N=2343)$ were recruited from an ongoing prospective cohort study on pregnancy-related pelvic girdle pain in the Netherlands. ${ }^{13}$ Pregnant women with an alternative lifestyle $(N$ $=491$ ) were recruited through organic food shops, anthroposophic doctors and midwives, Steiner schools, and magazines.

Beginning halfway during recruitment of the cohort (subjects recruited from January 2002 onward), fecal samples were collected from infants $(N=1176)$ at the age of 1 month. Subjects received a feces tube with spoon (Sarstedt, Nümbrecht, Germany), together with a sanitary napkin, an instruction form, and a brief questionnaire (feces questionnaire). Parents collected a fecal sample by placing a sanitary napkin in the diaper (to prevent absorption of the feces by the diaper) and collecting the feces out of the napkin into the collection tube, and they sent the sample as soon as possible (the same day) to the Department of Medical Microbiology at the University Hospital of Maastricht, by mail. Exclusion criteria were insufficient amount of feces $(<1 \mathrm{~g})$, feces collected before the age of 3 weeks or after the age of 6 weeks, and missing feces questionnaire.

\section{Information on Potential Determinants}

During pregnancy and the first months of the infant's life, information on perinatal determinants of the child's health, as well as hygiene, infections, nutrition, child rearing, and other lifestyle characteristics, was collected for all members of the cohort with repeated questionnaires. On the basis of these questionnaires, the following variables were selected as potential determinants of gut microbiotic composition: maternal education (lower education, vocational education, higher general secondary/preuniversity education, or higher vocational/academic education); maternal diet, defined as (1) regular diet ( $>50 \%$ of meat, eggs, vegetables, fruit, and milk of regular origin), (2) vegetarian diet (no meat but other products mainly of regular origin), (3) organic/biodynamic diet $(>50 \%$ of meat, eggs, vegetables, fruit, and milk of organic or biodynamic origin), or (4) organic/ biodynamic vegetarian diet; maternal probiotic use during pregnancy (frequency of consumption of dairy products with additional lactic acid-producing bacteria); 
maternal antibiotic use during last month of pregnancy (yes or no); prolonged rupture of membranes $(<24$ or $>24$ hours before delivery); place and mode of delivery (vaginal delivery at home, vaginal delivery in hospital, artificial delivery [forceps delivery and vacuum extraction] in hospital, or cesarean section in hospital); hospitalization of the infant after birth (days of hospitalization immediately after birth); infant gender (male or female); gestational age $(<37,37-41$, or $>41$ weeks); birth weight $(<2500,2500-4500$, or $>4500 \mathrm{~g})$; birth season (winter, spring, summer, or autumn); type of infant feeding during the first 1 month of life (exclusively breastfed, exclusively formula fed, or a combination); brand of infant formula (exclusive consumption of brand $\mathrm{A}$, brand $\mathrm{B}$ with locust bean gum, brand $\mathrm{C}$, or brand $\mathrm{D}$ with oligosaccharides during the first 1 month of life); antibiotic/antifungal use by the infant during the first 1 month of life (yes or no); fever of the infant in the first 1 month of life (yes or no); number of siblings (0, 1 or 2, or $>2$ ); living on a farm (yes or no); and having furry pets (none, cat, dog, other, or a combination).

\section{DNA Purification From Feces}

At the laboratory, fecal samples were 10-fold diluted in peptone/water (Oxoid CM0009) containing 20\% (vol/ vol) glycerol (Merck, Darmstadt, Germany) and were stored at $-20^{\circ} \mathrm{C}$ until analysis. For DNA isolation, 0.2 $\mathrm{mL}$ of the diluted feces was added to a $2-\mathrm{mL}$ vial containing $\sim 300 \mathrm{mg}$ of glass beads (diameter: $0.1 \mathrm{~mm}$ ) and $1.4 \mathrm{~mL}$ of ASL buffer from the QIAamp DNA stool minikit (Qiagen, Hilden, Germany), and the samples were disrupted in a mini-bead beater (Biospec Products, Bartlesville, OK) at $5000 \mathrm{rpm}$ for 3 minutes. Subsequently, the bacterial DNA was isolated from the samples with the QIAamp DNA stool mini kit, according to the instructions provided by the manufacturer. The DNA was eluted in a final volume of $200 \mu \mathrm{L}$.

\section{Microbial Analysis With Real-Time PCR Assays}

DNA from all fecal samples was subjected to real-time PCR assays for bifidobacteria, E coli, C difficile, Bacteroides fragilis group, lactobacilli, and total bacteria based on $16 \mathrm{~S}$ rDNA gene sequences (primers and probes are listed in Table 1). Development and validation of the real-time PCR assays were described in detail elsewhere. ${ }^{6,14-17}$ The 5'-nuclease technique was used for detection of bifidobacteria, $E$ coli, $C$ difficile, and members of the $B$ fragilis group. For detection of bifidobacteria, amplifications were conducted in a total volume of $50 \mu \mathrm{L}$, containing $1 \times$ TaqMan Universal PCR Master Mix (Applied Biosystems, Foster City, CA), $300 \mathrm{nmol} / \mathrm{L}$ levels of both primers, $150 \mathrm{nmol} / \mathrm{L}$ TaqMan probe, and $20 \mu \mathrm{L}$ of purified target DNA (see above). For $E$ coli, $C$ difficile, and $B$ fragilis group, amplifications were conducted in a total volume of $25 \mu \mathrm{L}$, containing $1 \times$ TaqMan Universal PCR Master Mix (Applied Biosystems), $900 \mathrm{nmol} / \mathrm{L}$ levels of both primers, $200 \mathrm{nmol} / \mathrm{L}$ TaqMan probe, and $10 \mu \mathrm{L}$ of purified target DNA. The amplification (2 minutes at $50^{\circ} \mathrm{C}, 10$ minutes at $95^{\circ} \mathrm{C}$, and 42 cycles of 15 seconds at $95^{\circ} \mathrm{C}$ and 1 minute at $60^{\circ} \mathrm{C}$ ) and detection were conducted with an Applied Biosystems Prism 7000 sequence detection system (Applied Biosystems).

For quantification of lactobacilli and total bacterial load, real-time detection of PCR products was conducted with SYBR Green I (Bio-Rad Laboratories, Hercules, CA). The PCR for lactobacilli was conducted in a total volume of $25 \mu \mathrm{L}$, containing $\mathrm{I} \times \mathrm{iQ}$ SYBR Green Supermix (Bio-Rad), $500 \mathrm{nmol} / \mathrm{L}$ levels of both primers, and 5 $\mu \mathrm{L}$ of purified target DNA. The amplification was conducted as follows: 5 minutes at $95^{\circ} \mathrm{C}$, followed by 35 cycles consisting of 15 seconds at $95^{\circ} \mathrm{C}, 20$ seconds at $58^{\circ} \mathrm{C}$, and 45 seconds at $72^{\circ} \mathrm{C}$, with a final extension step at $72^{\circ} \mathrm{C}$ for 5 minutes. After amplification, melting curve analysis was performed from $60^{\circ} \mathrm{C}$ to $95^{\circ} \mathrm{C}$, with increments of $0.5^{\circ} \mathrm{C}$ per 10 seconds. For quantification of the

TABLE 1 Primers and Probes Used in This Study

\begin{tabular}{|c|c|c|c|c|}
\hline $\begin{array}{c}\text { Target Organisms } \\
\text { (Amplicon Size) }\end{array}$ & Primer/Probe & Sequence $\left(5^{\prime}\right.$ to $\left.3^{\prime}\right)$ & $T_{\mathrm{m}^{\prime}}{ }^{\circ} \mathrm{C}$ & Source \\
\hline \multirow[t]{3}{*}{ Bifidobacterium spp (126 bp) } & Forward primer & GCGTGCTTAACACATGCAAGTC & 59 & Ref 6 \\
\hline & Reverse primer & CACCCGTTCCAGGAGCTAT & 59 & Ref 6 \\
\hline & Probe & TCACGCATTACTCACCCGTTCGCC & 70 & Ref 6 \\
\hline \multirow[t]{3}{*}{ E coli (96 bp) } & Forward primer & CATGCCGCGTGTATGAAGAA & 59 & Ref 14 \\
\hline & Reverse primer & CGGGTAACGTCAATGAGCAAA & 59 & Ref 14 \\
\hline & Probe & TAПTAACПTACTCCCTТCCTCCCCGCTGAA & 68 & Ref 14 \\
\hline \multirow[t]{3}{*}{ C difficile (114 bp) } & Forward primer & TGAGCGATTACTTGGTAAAGA & 58 & Ref 6 \\
\hline & Reverse primer & TGTACTGGCTCACCПTGATATTCA & 59 & Ref 6 \\
\hline & Probe & CCACGCGTTACTCACCCGTCCG & 69 & Ref 6 \\
\hline \multirow[t]{3}{*}{ B fragilis group (92 bp) } & Forward primer & CGGAGGATCCGAGCGTA & 58 & This study \\
\hline & Reverse primer & CCGCAAACПTCACAACTGACПTA & 59 & Ref 43 \\
\hline & Probe & CGCTCCCПTAAACCCAATAAATCCGG & 68 & This study \\
\hline \multirow[t]{2}{*}{ Lactobacillus spp (341 bp) } & Forward primer & AGCAGTAGGGAATCTTCCA & 59 & Refs 16 and 44 \\
\hline & Reverse primer & CACCGCTACACATGGAG & 59 & Refs 16 and 45 \\
\hline \multirow[t]{2}{*}{ Total count (467 bp) } & Forward primer & TCCTACGGGAGGCAGCAGT & 59 & Ref 17 \\
\hline & Reverse primer & GGACTACCAGGGTATCTAATCCTGTT & 58 & Ref 17 \\
\hline
\end{tabular}

$T_{m}$ indicates melting temperature; bp, base pairs 
total bacterial load, amplifications were conducted in a total volume of $25 \mu \mathrm{L}$, containing $1 \times$ iQ SYBR Green Supermix (Bio-Rad), $300 \mathrm{nmol} / \mathrm{L}$ levels of both primers, and $5 \mu \mathrm{L}$ of purified target DNA. The amplification consisted of 4 minutes at $95^{\circ} \mathrm{C}$ and 30 seconds at $60^{\circ} \mathrm{C}$, followed by 35 cycles of 30 seconds at $60^{\circ} \mathrm{C}, 15$ seconds at $95^{\circ} \mathrm{C}$, and 30 seconds at $60^{\circ} \mathrm{C}$. Finally, melting curve analysis was performed from $60^{\circ} \mathrm{C}$ to $95^{\circ} \mathrm{C}$, with increments of $0.5^{\circ} \mathrm{C}$ per 10 seconds. Amplification, melting curve analysis, and detection were conducted with the MyiQ single-color, real-time PCR detection system (BioRad).

\section{Statistical Analyses}

Values of $\log _{10}$ colony-forming units (CFU) per gram for the bacterial groups and species were calculated for each stool sample from the threshold cycle values by using the constructed standard curves. The prevalence of colonization was expressed as the percentage of infants colonized with a specific bacterial group or species. To determine the unadjusted overall effects of the individual determinants on the prevalence and counts of the bacteria simultaneously, the Mann-Whitney rank-sum test was used.

To analyze the effects of the individual determinants, with adjustment for all other determinants, 2 multivariate approaches were used. First, linear regression analyses were used to examine the effects of the determinants on the bacterial counts. In the linear regression analyses, only infants who were colonized with the bacterial group or species were included. Total bacterial count was added as an additional independent variable to account for differences in the consistency of fecal samples. Second, logistic regression analyses were used to examine the effect of the determinants on the prevalence of colonization (colonized compared with not colonized). Both linear and logistic regression models included all of the determinants under study as independent variables and 1 of the bacterial groups or species as the dependent variable at a time. Length of hospitalization (in days) was included as a continuous variable in the regression models, whereas all other independent variables were incorporated as categorical variables.

To limit the chance of falsely rejecting the null hypothesis (no association) as a result of multiple testing, we chose to set $\alpha$ at .01 (2-sided), instead of the usual .05 . Therefore, we present $99 \%$ confidence intervals (CIs) for the odds ratios (ORs) from logistic regression analyses.

\section{Ethical Considerations}

The KOALA Study was approved by the ethics committee of the University Hospital of Maastricht, and all parents signed informed consent for the study.

\section{RESULTS}

\section{Study Samples}

Fecal samples from a total of 1176 infants were collected. After exclusion of samples that were of insufficient amount $(n=65)$, samples that were collected before the age of 3 weeks or after the age of 6 weeks $(n=54)$, and samples for which the feces questionnaire was missing $(n=25)$, fecal samples from 1032 infants were included for analysis.

Almost all infants were colonized with bifidobacteria, and these bacteria outnumbered all other bacterial groups and species (Table 2). The majority of infants were also colonized with $E$ coli and members of the $B$ fragilis group, whereas both the prevalence and counts of lactobacilli and $C$ difficile were much lower.

Table 3 shows the prevalence and counts of the bacterial groups and species for the individual determinants under study. In Table 4, the associations between these determinants and the prevalence and counts of the fecal bacteria under study, as determined in the multivariate analyses, are presented. More-detailed information on these associations, including regression coefficients and ORs from the linear and logistic regression analyses, is shown in Table 5.

\section{Maternal Education, Diet, Antibiotic Use, and Probiotic Use}

More than one half of the women in this population ( $n$ $=572$ ) had a higher vocational or academic degree. Maternal education was not associated, however, with the infants' gut microbiotic composition.

Infants whose mothers consumed an organic or biodynamic diet seemed to have slightly lower numbers of $E$ coli in their stools than did infants whose mothers consumed a regular diet (Table 3); however, this association was not observed in the multivariate analysis (data not shown). Mothers who consumed an organic diet more often $(95 \%)$ breastfed their infants exclusively, compared with mothers who consumed a regular diet $(59 \%)$, which suggests that the type of infant feeding was the underlying cause of the association between maternal diet and infant's microbiotic composition in the univariate analysis. Probiotic use and antibiotic use by

TABLE 2 Median Counts and Prevalence of Selected Gut Bacteria in Feces of Infants 1 Month of Age $(n=1032)$

\begin{tabular}{|c|c|c|c|c|c|c|}
\hline & Bifidobacteria & E coli & C difficile & B fragilis Group & Lactobacilli & Total \\
\hline Median counts (range), $\log _{10}$ CFU/g feces & $10.68(6.84-11.56)$ & $9.35(5.91-10.79)$ & $5.32(2.70-9.57)$ & $9.28(5.74-10.44)$ & $8.66(7.92-10.73)$ & $11.12(9.43-12.14)$ \\
\hline Prevalence, \% & 98.6 & 87.7 & 25.0 & 81.6 & 32.4 & 100 \\
\hline
\end{tabular}


TABLE 3 Median Counts and Prevalence of Colonization With Selected Gut Bacteria in Feces of Infants 1 Month of Age $(n=1032)$

\begin{tabular}{|c|c|c|c|c|c|c|c|c|c|c|c|c|}
\hline \multirow[t]{2}{*}{ Characteristics } & \multirow[t]{2}{*}{ No. } & \multicolumn{2}{|c|}{ Bifidobacteria } & \multicolumn{2}{|r|}{ Ecoli } & \multicolumn{2}{|c|}{ C difficile } & \multicolumn{2}{|c|}{ B fragilis Group } & \multicolumn{2}{|c|}{ Lactobacilli } & \multirow{2}{*}{$\begin{array}{r}\text { Total Counts, } \\
\text { Median, log } 10 \\
\text { CFU/g Feces }\end{array}$} \\
\hline & & $\begin{array}{c}\text { Counts, } \\
\text { Median, } \\
\log _{10} \\
\text { CFU/g } \\
\text { Feces }\end{array}$ & $\begin{array}{c}\text { Prevalence, } \\
\%\end{array}$ & $\begin{array}{c}\text { Counts, } \\
\text { Median, } \\
\log _{10} \\
\text { CFU/g } \\
\text { Feces }\end{array}$ & $\begin{array}{c}\text { Prevalence, } \\
\%\end{array}$ & $\begin{array}{c}\text { Counts, } \\
\text { Median, } \\
\log _{10} \\
\text { CFU/g } \\
\text { Feces }\end{array}$ & $\begin{array}{l}\text { Prevalence, } \\
\text { \% }\end{array}$ & $\begin{array}{c}\text { Counts, } \\
\text { Median, } \\
\log _{10} \\
\text { CFU/g } \\
\text { Feces }\end{array}$ & $\begin{array}{l}\text { Prevalence, } \\
\text { \% }\end{array}$ & $\begin{array}{c}\text { Counts, } \\
\text { Median, } \\
\log _{10} \\
\text { CFU/g } \\
\text { Feces }\end{array}$ & $\begin{array}{l}\text { Prevalence, } \\
\text { \% }\end{array}$ & \\
\hline \multicolumn{13}{|l|}{ Maternal education } \\
\hline Lower educationa & 75 & 10.71 & 100 & 9.47 & 92 & 4.95 & 24 & 9.32 & 77 & 8.87 & 39 & 11.16 \\
\hline Vocational & 242 & 10.73 & 98 & 9.43 & 91 & 6.37 & 25 & 9.41 & 86 & 8.65 & 34 & 11.18 \\
\hline $\begin{array}{l}\text { Higher general } \\
\text { secondary/preuniversit }\end{array}$ & $\begin{array}{l}107 \\
\text { ty }\end{array}$ & 10.68 & 97 & 9.41 & 88 & 5.49 & 19 & 9.29 & 80 & 8.66 & 31 & 11.06 \\
\hline $\begin{array}{l}\text { Higher } \\
\text { vocational/academic } \\
\text { education }\end{array}$ & 572 & 10.65 & 99 & 9.24 & 86 & 5.30 & 25 & 9.21 & 80 & 8.64 & 30 & 11.08 \\
\hline \multicolumn{13}{|l|}{ Maternal diet ${ }^{b}$} \\
\hline Regulara & 723 & 10.67 & 99 & 9.49 & 89 & 5.40 & 26 & 9.39 & 82 & 8.70 & 34 & 11.15 \\
\hline Organic/biodynamic & 49 & 10.56 & 98 & 8.91 & $82^{c}$ & 6.70 & 16 & 8.93 & 75 & 8.51 & 33 & 10.92 \\
\hline Vegetarian & 47 & 10.63 & 98 & 9.06 & 85 & 6.76 & 17 & 9.00 & 81 & 8.66 & 32 & 11.05 \\
\hline $\begin{array}{l}\text { Organic/biodynamic } \\
\text { vegetarian }\end{array}$ & 16 & 10.61 & 94 & 8.66 & 88 & 4.17 & 25 & 8.16 & 69 & 8.48 & 38 & 10.91 \\
\hline \multicolumn{13}{|l|}{ Maternal probiotic use ${ }^{\mathrm{b}}$} \\
\hline Never/sporadica & 814 & 10.67 & 99 & 9.30 & 88 & 5.06 & 25 & 9.24 & 82 & 8.64 & 32 & 11.10 \\
\hline $\begin{array}{l}\text { Several times per } \\
\text { month }\end{array}$ & 100 & 10.62 & 98 & 9.23 & 82 & 6.74 & 21 & 9.36 & 75 & 8.68 & 34 & 11.12 \\
\hline Several times per week & 65 & 10.75 & 100 & 9.45 & 95 & 5.30 & 39 & 9.29 & 83 & 8.74 & 39 & 11.24 \\
\hline Daily & 23 & 10.48 & 100 & 9.71 & 70 & 5.40 & 13 & 9.34 & 83 & 8.71 & 35 & 11.21 \\
\hline \multicolumn{13}{|l|}{ Maternal antibiotic use } \\
\hline $\mathrm{No}^{\mathrm{a}}$ & 972 & 10.68 & 99 & 9.32 & 88 & 5.10 & 25 & 9.28 & 82 & 8.65 & 32 & 11.12 \\
\hline Yes & 38 & 10.60 & 92 & 9.48 & 95 & 5.92 & 16 & 9.30 & 74 & 8.68 & 50 & 11.13 \\
\hline \multicolumn{13}{|l|}{ Rupture of membranes } \\
\hline$\leq 24 \mathrm{~h}^{\mathrm{a}}$ & 996 & 10.67 & 99 & 9.36 & 88 & 5.30 & 25 & 9.28 & 82 & 8.68 & 32 & 11.12 \\
\hline$>24 h$ & 36 & 10.61 & 100 & 8.93 & 89 & 6.97 & 19 & 9.23 & 78 & 8.50 & 31 & 11.05 \\
\hline \multicolumn{13}{|l|}{$\begin{array}{l}\text { Place and mode of } \\
\text { delivery }\end{array}$} \\
\hline $\begin{array}{l}\text { Natural delivery at } \\
\text { home }^{\text {a }}\end{array}$ & 480 & 10.67 & 99 & 9.09 & 85 & 4.20 & 19 & 9.21 & 83 & 8.58 & 32 & 11.02 \\
\hline $\begin{array}{l}\text { Natural delivery in } \\
\text { hospital }\end{array}$ & 346 & 10.74 & 99 & 9.54 & $91^{\mathrm{e}}$ & 5.45 & $26^{c}$ & 9.40 & 85 & 8.65 & 34 & $11.18^{e}$ \\
\hline $\begin{array}{l}\text { Artificial delivery in } \\
\text { hospital }\end{array}$ & 76 & 10.80 & 100 & 9.73 & $91^{\mathrm{e}}$ & 6.19 & $34^{c}$ & 9.60 & 87 & 8.50 & 30 & $11.36^{e}$ \\
\hline $\begin{array}{l}\text { Cesarean section in } \\
\text { hospital }\end{array}$ & 108 & 10.38 & $96^{e}$ & 9.59 & $88^{c}$ & 6.36 & $42^{e}$ & 6.67 & $63^{e}$ & 8.87 & 32 & 11.11 \\
\hline \multicolumn{13}{|l|}{ Hospitalization after birth } \\
\hline $\mathrm{No}^{\mathrm{a}}$ & 737 & 10.69 & 99 & 9.24 & 87 & 4.38 & 20 & 9.27 & 83 & 8.58 & 32 & 11.10 \\
\hline $1 d$ & 91 & 10.77 & 100 & 9.57 & 90 & 6.60 & 30 & 9.60 & 81 & 8.68 & 33 & $11.33^{c}$ \\
\hline $2-3 d$ & 85 & 10.65 & 100 & 9.72 & $93^{\mathrm{e}}$ & 6.39 & $40^{e}$ & 9.41 & 79 & 8.88 & 37 & 11.23 \\
\hline $4-6 d$ & 73 & 10.36 & $96 e$ & 9.76 & 89 & 6.03 & $43^{e}$ & 6.56 & $68^{e}$ & 8.71 & 41 & 11.08 \\
\hline$\geq 7 \mathrm{~d}$ & 25 & 10.25 & $96^{c}$ & 9.40 & 88 & 6.94 & $40^{c}$ & 8.42 & 80 & 9.44 & 28 & 10.96 \\
\hline \multicolumn{13}{|l|}{ Gender } \\
\hline Male & 531 & 10.64 & 99 & 9.37 & 89 & 5.61 & 24 & 9.20 & 80 & 8.76 & 32 & 11.10 \\
\hline Female & 501 & 10.70 & 98 & 9.28 & 86 & 5.06 & 25 & 9.34 & 83 & 8.58 & 33 & 11.12 \\
\hline \multicolumn{13}{|l|}{ Gestational age at birth } \\
\hline$<37$ wk (premature) & 11 & 10.53 & 91 & 9.02 & 73 & 7.12 & $64^{c}$ & 8.95 & 82 & 8.80 & 27 & 10.80 \\
\hline $37-41 w k^{a}$ & 860 & 10.68 & 99 & 9.30 & 87 & 5.06 & 23 & 9.27 & 82 & 8.61 & 33 & 11.12 \\
\hline$>41$ wk (postmature) & 37 & 10.44 & 100 & 9.77 & 84 & 6.99 & 35 & 9.51 & 78 & 8.72 & 32 & 11.14 \\
\hline \multicolumn{13}{|l|}{ Birth weight } \\
\hline$<2500 \mathrm{~g}$ & 11 & 10.45 & 100 & 8.67 & 100 & 7.12 & 27 & 9.31 & 82 & 9.12 & 36 & 11.28 \\
\hline $2500-4500 \mathrm{~g}^{\mathrm{a}}$ & 906 & 10.67 & 99 & 9.32 & 87 & 5.08 & 24 & 9.30 & 82 & 8.65 & 33 & 11.12 \\
\hline$>4500 \mathrm{~g}$ & 26 & 10.61 & 100 & 9.59 & 85 & 6.07 & 23 & 9.30 & 77 & 8.60 & 35 & 11.03 \\
\hline Birth season & & & & & & & & & & & & \\
\hline Wintera & 285 & 10.67 & 99 & 9.37 & 85 & 5.61 & 22 & 9.20 & 81 & 8.65 & 32 & 11.11 \\
\hline Spring & 241 & 10.65 & 96 & 9.26 & 88 & 6.28 & 25 & 9.44 & 82 & 8.87 & 37 & 11.13 \\
\hline Summer & 286 & 10.55 & 99 & 9.23 & 92 & 4.60 & 23 & 9.04 & 82 & 8.65 & 33 & 11.04 \\
\hline Autumn & 216 & 10.84 & 99 & 9.53 & 86 & 4.74 & 30 & 9.31 & 81 & 8.40 & 26 & 11.21 \\
\hline
\end{tabular}




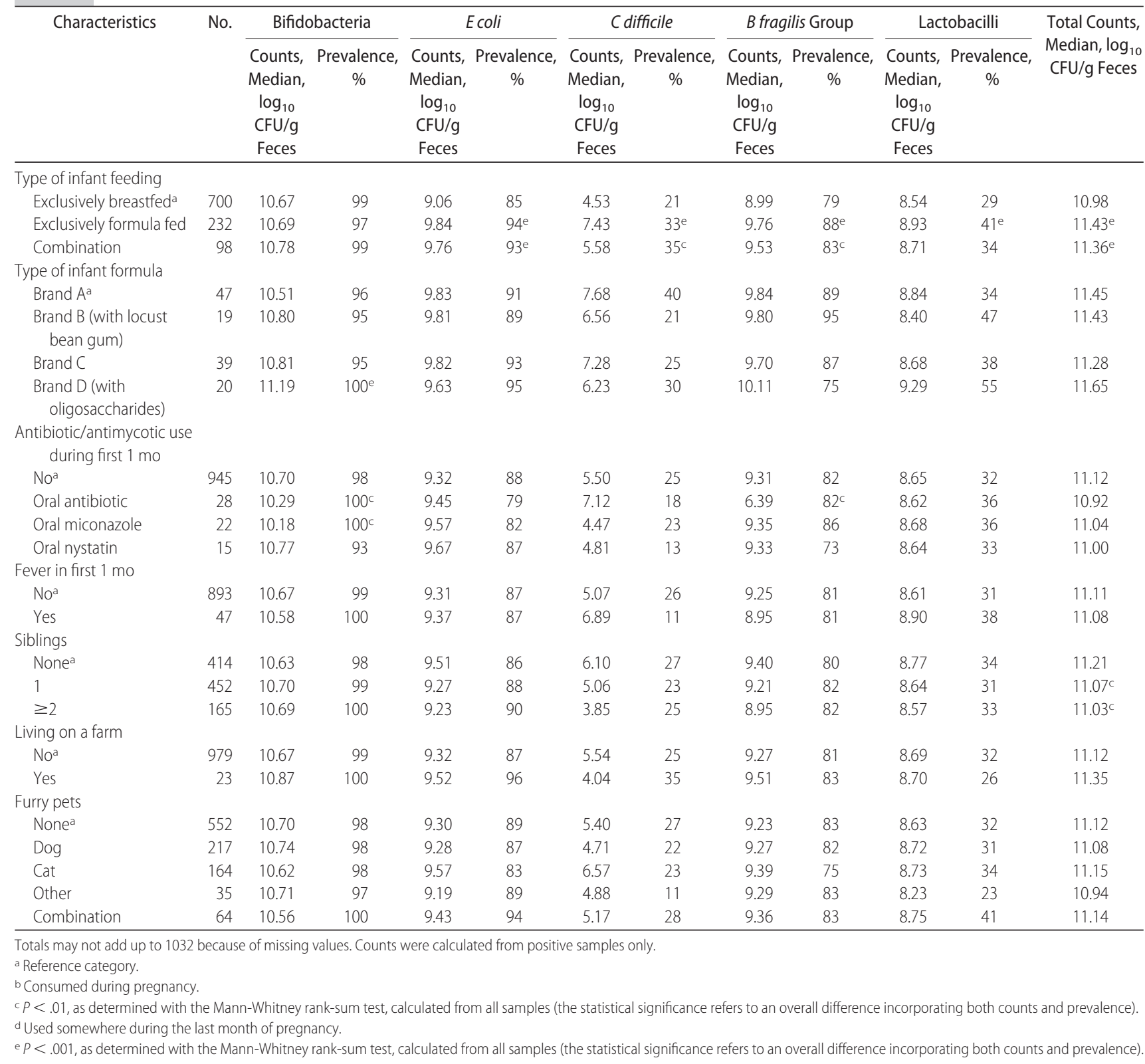

the mother during pregnancy had no influence on the infant's gut microbiotic composition.

\section{Delivery and Birth Characteristics}

Amniotic membranes ruptured $>24$ hours before delivery for only 36 women. We found no association between prolonged rupture of membranes among women and the gut microbiotic composition of their infants.

More than one half of the infants were born in the hospital, and $\sim 10 \%$ of all infants were born through cesarean section. In comparison with vaginal delivery at home, cesarean section resulted in lower colonization rates and counts of bifidobacteria and $B$ fragilis-group species, whereas prevalence and counts of $C$ difficile and counts of $E$ coli were higher. The most-pronounced dif- ferences in colonization were seen for the $B$ fragilis group and $C$ difficile; compared with infants born vaginally at home, the median counts of $B$ fragilis-group bacteria and $C$ difficile were $\sim 100$-fold lower and $\sim 100$-fold higher, respectively, for infants born through cesarean section (Table 3). After adjustment for the other determinants, cesarean section was still associated with lower counts of bifidobacteria, a lower colonization rate and counts of $B$ fragilis-group species, and higher counts of $C$ difficile. In contrast, counts and colonization rate of $E$ coli were no longer associated with cesarean section in the adjusted analyses. This is illustrated in Table 5 by a regression coefficient for counts close to 0 and an OR for prevalence close to 1.0. Although vaginal delivery and artificial delivery in the hospital seemed to be associated with 
TABLE 4 Associations Between Determinants and Selected Gut Bacteria in Feces of Infants 1 Month of Age, as Determined in Multivariate Analyses

\begin{tabular}{|c|c|c|c|c|c|c|c|c|c|c|}
\hline & \multicolumn{10}{|c|}{ Association } \\
\hline & \multicolumn{2}{|c|}{ Bifidobacteria } & \multicolumn{2}{|c|}{ Ecoli } & \multicolumn{2}{|c|}{ C difficile } & \multicolumn{2}{|c|}{ B fragilis Group } & \multicolumn{2}{|c|}{ Lactobacilli } \\
\hline & Counts & Prevalence & Counts & Prevalence & Counts & Prevalence & Counts & Prevalence & Counts & Prevalence \\
\hline $\begin{array}{l}\text { Cesarean section (compared } \\
\text { with vaginal delivery) }\end{array}$ & -- & ND & & & & + & -- & -- & & \\
\hline Hospitalization (d) & & ND & & & & + & & & & \\
\hline $\begin{array}{l}\text { Prematurity (compared with } \\
\text { term infants) }\end{array}$ & & ND & & & + & & & & & \\
\hline $\begin{array}{l}\text { Exclusive formula feeding } \\
\text { (compared with exclusive } \\
\text { breastfeeding) }\end{array}$ & & ND & & + & + & ++ & & + & & + \\
\hline Antibiotic use by infant (yes/no) & - & ND & & & & & -- & & & \\
\hline $\begin{array}{l}\text { Miconazole use by infant (yes/ } \\
\text { no) }\end{array}$ & - & ND & & & & & & & & \\
\hline Siblings (yes/no) & + & ND & & & & & & & & \\
\hline
\end{tabular}

Results for determinants with no statistically significant results for any of the bacteria are not presented. Associations between determinants and counts were examined with linear regression analyses; models included the following independent variables: maternal education, maternal diet, maternal probiotic use, maternal antibiotic use, rupture of membranes, place and mode of delivery, gender, gestational age, birth weight, birth season, hospitalization after birth, type of infant feeding, antibiotic/antimycotic use by infant, fever of infant, siblings, farm residence, furry pets, and total bacterial count. Associations between determinants and prevalence of colonization (colonized compared to not colonized) were examined with logistic regression analyses; models included the following variables: maternal education, maternal diet, maternal probiotic use, maternal antibiotic use, rupture of membranes, place and mode of delivery, gender, gestational age, birth weight, birth season, hospitalization after birth, type of infant feeding, antibiotic/antimycotic use by infant, fever of infant, siblings, farm residence, and furry pets. ND indicates not determined (logistic regression analysis of prevalence of bifidobacteria was not performed because $99 \%$ of infants were colonized); + , positive association, $P<.01 ;++$, positive association, $P<.001 ;-$, negative association, $P<.01 ;--$, negative association, $P<.001$.

higher counts and prevalences of $E$ coli and $C$ difficile, compared with home birth (Table 3), these associations were present only in the unadjusted analyses.

Hospitalization after birth was associated only with a higher $C$ difficile colonization rate after controlling for other determinants. The prevalence of $C$ difficile increased $\sim 13 \%$ per day of hospitalization, compared with nonhospitalized infants (OR: 1.13; 99\% CI: 1.01-1.25).

Only 11 infants in this study population were born premature ( $<37$ weeks). These infants were colonized more often with $C$ difficile (64\%, as opposed to $23 \%$ ), with considerably higher counts (7.12 $\log _{10} \mathrm{CFU} / \mathrm{g}$ feces, compared with $5.06 \log _{10} \mathrm{CFU} / \mathrm{g}$ feces), compared with term infants (Table 3). With adjustment for other determinants, the counts were still statistically significantly higher (Tables 4 and 5). The OR was still consistent with a higher colonization rate (OR: 4.47) but was not statistically significant, probably because of the low power caused by the small number of infants. No association was found between the gut microbiota and birth weight, birth season, or gender of the infant.

\section{Infant Feeding}

Most infants $(n=700)$ were breastfed exclusively up to the first 1 month of life, whereas 232 infants were formula fed exclusively and 98 infants received a combination of breastfeeding and formula feeding. Exclusively formula-fed infants were more often colonized with $E$ coli, $C$ difficile, $B$ fragilis group, and lactobacilli than were their exclusively breastfed counterparts, as shown in both the unadjusted (Table 3 ) and adjusted (Tables 4 and 5) analyses. The counts of $E$ coli, $C$ difficile, $B$ fragilis group, and lactobacilli were also significantly higher for formula-fed infants, compared with breastfed infants, in the unadjusted analyses. In the adjusted analyses, only counts of $C$ difficile were still significantly higher for formula-fed infants, whereas counts of both $E$ coli $(P=$ $.03)$ and $B$ fragilis ( $P=.027)$ still tended to be higher for formula-fed infants (not reaching the level of significance of $P<.01$ ) (Table 5).

In our population, 4 brands of formula were used frequently. Brand B contained locust bean gum and brand D was enriched with oligosaccharides, whereas the others were not. Infants fed exclusively with 1 of these 4 formulas were compared. As shown in Table 3, infants fed the oligosaccharide-enriched formula (brand D) harbored greater numbers of bifidobacteria in their stools. After adjustment for the other determinants under study, counts of bifidobacteria (coefficient: 0.60; $P=$ .04 ) and also counts of lactobacilli (coefficient: $0.75 ; P=$ .02) tended to be higher for infants fed formula D, compared with reference formula A (data not shown).

\section{Antibiotics, Antimycotic Agents, and Fever}

Oral use of antibiotics (mainly amoxicillin) by the infant during the first 1 month of life resulted in decreased numbers of bifidobacteria and $B$ fragilis-group species. Lower counts of bifidobacteria were also observed after oral administration of the antimycotic miconazole (Tables 3 and 4). Infants who experienced a fever in their first 1 month of life did not have different gut microbiotic composition, compared with infants without a fever. 


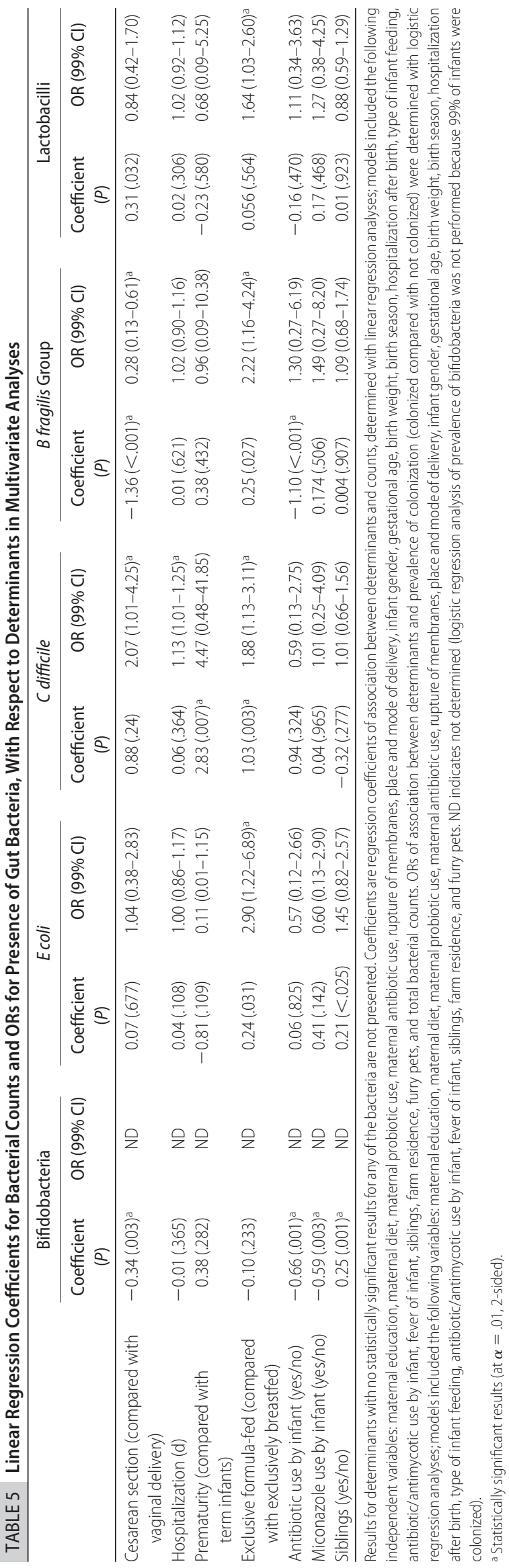

\section{Home Environment}

Infants with older siblings had lower total bacterial counts per gram of feces than did infants without siblings, as seen in the unadjusted analysis (Table 3). After adjustment for these differences in total bacterial counts and other potential differences between infants with and without siblings, a greater proportion of bifidobacteria was found for infants with older siblings, compared with infants without siblings (Tables 4 and 5). Infants' gut microbiota was not associated with farm residence or the presence of furry pets in the home, as determined in both the unadjusted (Table 3 ) and multivariate (data not shown) analyses.

\section{DISCUSSION}

To our knowledge, this is the first large, prospective, epidemiologic study on determinants of gut microbiotic composition in early infancy. As a consequence of the large number of infants in the KOALA study, we were able to study the potential determinants in a multivariate manner and to distinguish their independent effects. The fecal samples were analyzed with real-time quantitative PCR assays. This molecular approach can be applied to high-throughput analyses with frozen samples, which makes this technique very suitable for a largescale epidemiologic study such as this. Furthermore, real-time quantitative PCR analyses overcome many of the limitations of traditional bacteriologic culture techniques, such as the low sensitivity, the low level of reproducibility because of the multitude of species to be identified and quantified, and the time-consuming aspects of the conventional methods. ${ }^{14}$ However, molecular techniques based on amplification of 16S rDNA require that the microbial cells in the sample first be lysed for the extraction of DNA. There is a vast difference in the susceptibility of the cells of different microbial species to lytic procedures. When only 1 lytic method is used, it is unlikely that template DNA for the real-time PCR analysis is extracted with equal success from all species. ${ }^{18}$ Therefore, we chose to add a mechanical lysis step to the chemical lyses of the Qiagen stool mini kit.

A drawback of this study was the time between collection of the samples by the parents and processing of the samples in the laboratory, which was $\sim 1$ day. Ott et $\mathrm{al}^{19}$ demonstrated clearly that the total amount of bacterial DNA, as well as the diversity of the microbiota, decreased significantly over such a time period. However, they also showed that the similarity (determined with denaturing gradient gel electrophoresis) of fecal samples processed directly and those processed after 24 hours remained high. This means that the dominant microbiota seems to be relatively stable. Furthermore, the aim of the present population-based study was to examine differences in gut microbiotic composition between subjects. ${ }^{19}$ It is not likely that the possible changes 
in composition of the samples during transport were influenced by the determinants under study.

It was demonstrated previously that diet can have an influence on the gut microbiota. For example, introduction of an extreme vegan diet was shown to change bacterial fatty acid profiles in the feces. ${ }^{20}$ Also, an organic diet (consumption of foods that are produced without the use of synthetic inputs, such as synthetic fertilizers and pesticides, veterinary drugs, genetically modified seeds and breeds, preservatives, additives, and irradiation) may influence the gut microbiota, because organically produced foods include spontaneously fermented vegetables containing lactobacilli. ${ }^{21}$ We hypothesized that the maternal diet not only might be a determinant of the mother's gut microbiota but also might influence her infant's gut microbiotic composition. Indeed, maternal diet seemed to have some influence on the offspring's microbiota, as shown in the univariate analysis; $E$ coli counts were lower and the prevalence and counts of $B$ fragilis-group species tended to be lower for infants of mothers consuming organic diets. However, this association disappeared completely after adjustment for other determinants. This can be explained at least in part by the fact that mothers who consume an organic diet more often breastfeed their infants, compared with mothers with regular diets. This emphasizes clearly the need for multivariate analysis when the effects of determinants of gut microbiotic composition are studied.

We did not find an association between maternal use of probiotics during pregnancy and the intestinal microbiotic composition of the offspring at the age of 1 month. However, it is not unlikely that transfer of probiotic bacterial strains from mother to child occurs, especially when the child is exposed to maternal feces during vaginal delivery. Although probiotic bacteria do not colonize permanently the gut of adults, ${ }^{22,23}$ this might be different for neonates, who do not yet have an established gut microbiota. Indeed, Schultz et $\mathrm{al}^{24}$ confirmed such a transmission of probiotic strains from mother to child during birth; although the specific probiotic strain was present in very low numbers $\left(10^{4}-10^{5} \mathrm{CFU} / \mathrm{g}\right.$ feces $)$ for most infants, it persisted at least until the age of 6 months. In the present study, we did not investigate the presence of specific probiotic strains but focused on the total numbers of bifidobacteria and lactobacilli. Consequently, a putative small contribution of probiotic bacterial strains to the total number of lactobacilli or bifidobacteria would not be noticed. Furthermore, the pregnant women in our cohort used a wide range of different probiotic products, including different strains. This heterogeneity might explain why an association between probiotic use by the mothers and the gut microbiotic composition of the infants was not found. Firm conclusions regarding the effects of changes in the maternal microbiota itself cannot be made, however, be- cause we have no data on the impact of maternal diet and probiotic use on the mother's own microbiota.

In addition to maternal diet and probiotic use, antibiotic use by the mother during the last month of pregnancy was selected as a potential determinant of the infant's microbiota. This was based on the notion that changes in maternal microbiota could affect the infant's microbiota. However, as for the previous 2 determinants, maternal antibiotic use was not found to be associated with any of the examined gut bacteria.

Prolonged rupture of amniotic membranes before delivery increases the risk of fetal infection, especially with group B streptococci. ${ }^{25}$ However, we found no association between prolonged rupture of membranes and the commensal gut bacteria under study. Because the presence of streptococci was not examined, we cannot draw any conclusions about the association between prolonged rupture of membranes and the presence of this specific group of bacteria in the infant's gut.

The colonization rate and counts of the $B$ fragilis group differed most markedly between vaginally delivered infants and infants born through cesarean section. This is in agreement with 2 previous studies, which also found levels of members of the $B$ fragilis group to be greatly reduced as a result of cesarean section., ${ }^{4,26}$ Furthermore, we found bifidobacterial counts to be lower (although this was less pronounced) and colonization rates of $C$ difficile to be higher for infants born through cesarean section, compared with infants born vaginally at home.

After adjustment for potential confounding by the other determinants, the hospital environment itself had an effect only on the colonization rate of $C$ difficile. Indeed, it is thought generally that infants are being colonized with this spore-forming, anaerobic, microorganism mainly through the hospital environment. It was reported previously that vaginal swabs collected just before delivery were uniformly negative for this organism. ${ }^{27}$ In contrast, $C$ difficile was isolated from hands and stools of healthy hospital personnel and from a NICU, where spores may persist for months. ${ }^{28}$ Although carriage of $C$ difficile by healthy adults is uncommon, ${ }^{29}$ the relatively high colonization rates among asymptomatic infants found in our study are in accordance with findings from previous studies. ${ }^{30-33}$ The highest carriage rate of $C$ difficile in our birth cohort was among premature infants; $64 \%$ of the infants born before 37 weeks of gestation were colonized. Prematurity is associated strongly with hospitalization, which could explain in part the relatively high prevalence of $C$ difficile in preterm infants. However, after controlling for other determinants, the counts of $C$ difficile were still significantly higher in preterm infants than in term infants. Several factors that were not included in the present study may account for the higher numbers of $C$ difficile in preterm infants, such as the immature gastrointestinal tract and delayed oral feeding. 
Like previous studies, ${ }^{11,34,35}$ we found that breastfed infants had a microbiota dominated by bifidobacteria, with rates of colonization with $E$ coli, $C$ difficile, $B$ fragilisgroup species, and lactobacilli that were significantly lower than those for formula-fed infants. Infants fed exclusively with a formula supplemented with a mixture of galactooligosaccharides and fructooligosaccharides (brand D) had higher counts of bifidobacteria and lactobacilli in their stools, compared with infants fed an unsupplemented formula. Although the compositions of the formulas differed not only in the oligosaccharide supplementation, it is well known that supplementation with oligosaccharides increases counts of lactic acid-producing bacteria. ${ }^{36,37}$ As opposed to the time of this study, presently most formulas are supplemented with oligosaccharides in the Netherlands; therefore, differences in gut microbiotic composition as a result of different formulas probably have disappeared.

Although the use of antibiotics may have a major effect on the composition of the gut microbiota, the effect differs between antibiotics. ${ }^{38}$ Because of the small number of infants in our cohort who received oral antibiotic therapy in their first 1 month, we were not able to distinguish between different antibiotics. Nevertheless, oral antibiotic administration had clear-cut effects on the anaerobic microbiota, with counts of bifidobacteria and Bacteroides being decreased.

In the unadjusted analyses, total bacterial counts were lower in infants with siblings than in first children. After adjustment for these differences in total bacterial counts and all other determinants, the proportion of bifidobacteria was significantly higher in infants with older siblings, compared with first children, and counts of $E$ coli also tended to be higher in infants with older siblings. Again, this emphasizes the importance of multivariate analyses in studying a range of determinants of the gut microbiota. Studies on the etiology of allergic diseases have often found a protective effect of older siblings. ${ }^{39}$ This sibling effect has been hypothesized to be a marker of early-life infections. However, direct evidence for this hypothesis is lacking. ${ }^{40}$ Because allergic diseases have also been linked to aberrant gut microbiotic composition, ${ }^{41,42}$ it has been suggested that this sibling effect in allergy could be partly attributable to the commensal gut microbiotic composition. To our knowledge, we are the first to demonstrate that having older siblings is indeed associated with the composition of the gut microbiota. It is clear, however, that the difference between children with and without siblings is small, and the clinical relevance of this difference remains to be elucidated.

\section{CONCLUSIONS}

Infant feeding had a major effect on the gut microbiotic composition in infants at the age of 1 month. Breastfed infants were less often colonized with bacteria other than bifidobacteria, compared with formula-fed infants. The effect of mode of delivery was also of major importance, especially regarding Bacteroides. Although passing through the birth canal (vaginal delivery) and thus coming in contact with maternal feces was associated strongly with the infant's gut microbiota, we found no effect on the infant's gut microbiota of determinants that potentially influence the microbial composition of maternal feces (maternal diet, antibiotic use, and probiotic use). Hospitalization and prematurity were both associated positively with $C$ difficile. Antibiotic use reduced greatly the levels of obligate anaerobes (bifidobacteria and Bacteroides), whereas having older siblings was associated with slightly higher bifidobacterial counts. Term infants who were born vaginally at home and were breastfed exclusively seemed to have the most "beneficial" gut microbiota, with the highest numbers of bifidobacteria and lowest numbers of $C$ difficile and $E$ coli.

\section{ACKNOWLEDGMENTS}

This study was supported by grants from the Dutch Asthma Foundation, Triodos Foundation (Netherlands), and Royal Friesland Foods.

We thank Hanne Adams for assistance with analyses of fecal samples and all of the mothers and infants for participation in the KOALA study.

\section{REFERENCES}

1. Guarner F, Malagelada JR. Gut flora in health and disease. Lancet. 2003;361:512-519

2. Rastall RA. Bacteria in the gut: friends and foes and how to alter the balance. J Nutr. 2004;134(suppl):2022S-2026S

3. Bezirtzoglou E. The intestinal microflora during the first weeks of life. Anaerobe. 1997;3:173-177

4. Gronlund MM, Lehtonen OP, Eerola E, Kero P. Fecal microflora in healthy infants born by different methods of delivery: permanent changes in intestinal flora after cesarean delivery. J Pediatr Gastroenterol Nutr. 1999;28:19-25

5. Heavey PM, Rowland IR. The gut microbiology of the developing infant: microbiology and metabolism. Microbiol Ecol Health Dis. 1999; 11:75-83

6. Penders J, Vink C, Driessen C, London N, Thijs C, Stobberingh E. Quantification of Bifidobacterium spp, Escherichia coli and Clostridium difficile in faecal samples of breast-fed and formulafed infants by real-time PCR. FEMS Microbiol Lett. 2005;243: $141-147$

7. Gewolb IH, Schwalbe RS, Taciak VL, Harrison TS, Panigrahi P. Stool microflora in extremely low birthweight infants. Arch Dis Child Fetal Neonatal Ed. 1999;80:F167-F173

8. Bennet R, Eriksson M, Nord CE. The fecal microflora of 1-3month-old infants during treatment with eight oral antibiotics. Infection. 2002;30:158-160

9. Blakey JL, Lubitz L, Barnes GL, Bishop RF, Campbell NT, Gillam GL. Development of gut colonisation in pre-term neonates. J Med Microbiol. 1982;15:519-529

10. Stark PL, Lee A. The bacterial colonization of the large bowel of pre-term low birth weight neonates. J Hyg. 1982;89:59-67

11. Stark PL, Lee A. The microbial ecology of the large bowel of breast-fed and formula-fed infants during the first year of life. J Med Microbiol. 1982;15:189-203

12. Kummeling I, Thijs C, Penders J, et al. Etiology of atopy in 
infancy: the KOALA Birth Cohort Study. Pediatr Allergy Immunol. 2005;16:679-684

13. Bastiaanssen JM, de Bie RA, Bastiaenen CH, et al. Etiology and prognosis of pregnancy-related pelvic girdle pain: design of a longitudinal study. BMC Public Health. 2005;5:1

14. Huijsdens XW, Linskens RK, Mak M, Meuwissen SG, Vandenbroucke Grauls CM, Savelkoul PH. Quantification of bacteria adherent to gastrointestinal mucosa by real-time PCR. J Clin Microbiol. 2002;40:4423-4427

15. Ott SJ, Musfeldt M, Ullmann U, Hampe J, Schreiber S. Quantification of intestinal bacterial populations by real-time PCR with a universal primer set and minor groove binder probes: a global approach to the enteric flora. J Clin Microbiol. 2004;42: $2566-2572$

16. Rinttila T, Kassinen A, Malinen E, Krogius L, Palva A. Development of an extensive set of 16S rDNA-targeted primers for quantification of pathogenic and indigenous bacteria in faecal samples by real-time PCR. J Appl Microbiol. 2004;97:1 166-1 177

17. Nadkarni MA, Martin FE, Jacques NA, Hunter N. Determination of bacterial load by real-time PCR using a broad-range (universal) probe and primers set. Microbiology. 2002;148: 257-266

18. Tannock GW. Analysis of the intestinal microflora: a renaissance. Antonie Van Leeuwenhoek. 1999;76:265-278

19. Ott SJ, Musfeldt M, Timmis KN, Hampe J, Wenderoth DF, Schreiber S. In vitro alterations of intestinal bacterial microbiota in fecal samples during storage. Diagn Microbiol Infect Dis. 2004;50:237-245

20. Peltonen R, Ling WH, Hanninen O, Eerola E. An uncooked vegan diet shifts the profile of human fecal microflora: computerized analysis of direct stool sample gas-liquid chromatography profiles of bacterial cellular fatty acids. Appl Environ Microbiol. 1992;58:3660-3666

21. Alm JS, Swartz J, Bjorksten B, et al. An anthroposophic lifestyle and intestinal microflora in infancy. Pediatr Allergy Immunol. 2002;13:402-411

22. Bouhnik Y, Pochart P, Marteau P, Arlet G, Goderel I, Rambaud JC. Fecal recovery in humans of viable Bifidobacterium sp ingested in fermented milk. Gastroenterology. 1992;102:875-878

23. Goossens D, Jonkers D, Russel M, Stobberingh E, Van Den Bogaard A, Stockbrügger R. The effect of Lactobacillus plantarum $299 \mathrm{~V}$ on the bacterial composition and metabolic activity in faeces of healthy volunteers: a placebo-controlled study on the onset and duration of effects. Aliment Pharmacol Ther. 2003;18: 495-505

24. Schultz M, Gottl C, Young RJ, Iwen P, Vanderhoof JA. Administration of oral probiotic bacteria to pregnant women causes temporary infantile colonization. J Pediatr Gastroenterol Nutr. 2004;38:293-297

25. Benitz WE, Gould JB, Druzin ML. Risk factors for early-onset group B streptococcal sepsis: estimation of odds ratios by critical literature review. Pediatrics. 1999;103(6). Available at: www.pediatrics.org/cgi/content/full/103/6/e77

26. Bennet R, Nord CE. Development of the faecal anaerobic microflora after caesarean section and treatment with antibiotics in newborn infants. Infection. 1987;15:332-336

27. Al Jumaili IJ, Shibley M, Lishman AH, Record CO. Incidence and origin of Clostridium difficile in neonates. J Clin Microbiol. 1984; 19:77-78
28. Kim KH, Fekety R, Batts $\mathrm{DH}$, et al. Isolation of Clostridium difficile from the environment and contacts of patients with antibiotic-associated colitis. $J$ Infect Dis. 1981;143:42-50

29. Knoop FC, Owens M, Crocker IC. Clostridium difficile: clinical disease and diagnosis. Clin Microbiol Rev. 1993;6:251-265

30. Tullus K, Aronsson B, Marcus S, Mollby R. Intestinal colonization with Clostridium difficile in infants up to 18 months of age. Eur J Clin Microbiol Infect Dis. 1989;8:390-393

31. Oguike JU, Emeruwa AC. Incidence of Clostridium difficile in infants in rural and urban areas of Nigeria. Microbiologica. 1990; 13:267-271

32. Merida V, Moerman J, Colaert J, Lemmens P, Vandepitte J. Significance of Clostridium difficile and its cytotoxin in children. Eur J Pediatr. 1986;144:494-496

33. Larson HE, Barclay FE, Honour P, Hill ID. Epidemiology of Clostridium difficile in infants. J Infect Dis. 1982;146:727-733

34. Benno Y, Sawada K, Mitsuoka T. The intestinal microflora of infants: composition of fecal flora in breast-fed and bottle-fed infants. Microbiol Immunol. 1984;28:975-986

35. Yoshioka H, Iseki K, Fujita K. Development and differences of intestinal flora in the neonatal period in breast-fed and bottlefed infants. Pediatrics. 1983;72:317-321

36. Moro GE, Mosca F, Miniello V, et al. Effects of a new mixture of prebiotics on faecal flora and stools in term infants. Acta Paediatr Suppl. 2003;91:77-79

37. Rinne MM, Gueimonde M, Kalliomaki M, Hoppu U, Salminen SJ, Isolauri E. Similar bifidogenic effects of prebiotic-supplemented partially hydrolyzed infant formula and breastfeeding on infant gut microbiota. FEMS Immunol Med Microbiol. 2005; 43:59-65

38. Edlund C, Nord CE. Effect on the human normal microflora of oral antibiotics for treatment of urinary tract infections. $J$ Antimicrob Chemother. 2000;46(suppl 1):41-48

39. Strachan DP. Family size, infection and atopy: the first decade of the "hygiene hypothesis." Thorax. 2000;55(suppl 1):S2-S10

40. Gibbs S, Surridge H, Adamson R, Cohen B, Bentham G, Reading R. Atopic dermatitis and the hygiene hypothesis: a casecontrol study. Int J Epidemiol. 2004;33:199-207

41. Bjorksten B, Naaber P, Sepp E, Mikelsaar M. The intestinal microflora in allergic Estonian and Swedish 2-year-old children. Clin Exp Allergy. 1999;29:342-346

42. Kalliomaki M, Kirjavainen P, Eerola E, Kero P, Salminen S, Isolauri E. Distinct patterns of neonatal gut microflora in infants in whom atopy was and was not developing. J Allergy Clin Immunol. 2001;107:129-134

43. Liu C, Song Y, McTeague M, Vu AW, Wexler H, Finegold SM. Rapid identification of the species of the Bacteroides fragilis group by multiplex PCR assays using group- and speciesspecific primers. FEMS Microbiol Lett. 2003;222:9-16

44. Walter J, Hertel C, Tannock GW, Lis CM, Munro K, Hammes WP. Detection of Lactobacillus, Pediococcus, Leuconostoc, and Weissella species in human feces by using group-specific PCR primers and denaturing gradient gel electrophoresis. Appl Environ Microbiol. 2001;67:2578-2585

45. Heilig HGHJ, Zoetendal EG, Vaughan EE, Marteau P, Akkermans ADL, de Vos WM. Molecular diversity of Lactobacillus spp and other lactic acid bacteria in the human intestine as determined by specific amplification of $16 \mathrm{~S}$ ribosomal DNA. Appl Environ Microbiol. 2002;68:114-123 


\section{Factors Influencing the Composition of the Intestinal Microbiota in Early Infancy}

John Penders, Carel Thijs, Cornelis Vink, Foekje F. Stelma, Bianca Snijders, Ischa Kummeling, Piet A. van den Brandt and Ellen E. Stobberingh

Pediatrics 2006;118;511-521

DOI: $10.1542 /$ peds. $2005-2824$

\section{Updated Information \\ \& Services}

References

Citations

Subspecialty Collections

Permissions \& Licensing

Reprints including high-resolution figures, can be found at: http://www.pediatrics.org/cgi/content/full/118/2/511

This article cites 42 articles, 11 of which you can access for free at:

http://www.pediatrics.org/cgi/content/full/118/2/511\#BIBL

This article has been cited by 11 HighWire-hosted articles: http://www.pediatrics.org/cgi/content/full/118/2/511\#otherarticle

This article, along with others on similar topics, appears in the following collection(s): Infectious Disease \& Immunity

http://www.pediatrics.org/cgi/collection/infectious_disease

Information about reproducing this article in parts (figures, tables) or in its entirety can be found online at: http://www.pediatrics.org/misc/Permissions.shtml

Information about ordering reprints can be found online: http://www.pediatrics.org/misc/reprints.shtml

\section{American Academy of Pediatrics}

